\title{
Synthesis of Certain Assimilatory and Dissimilatory Enzymes during Bacterial Adaptation to Growth on Trimethylamine
}

\author{
By CHRISTOPHER A. BOULTON AND PETER J. LARGE \\ Department of Biochemistry, University of Hull, Hull HU6 ${ }_{7} R X$
}

(Received I I March I977)

\begin{abstract}
During the adaptation of Pseudomonas aminovorans from growth on succinate to growth on trimethylamine, the following enzymes were synthesized in the lag phase before exponential growth on trimethylamine began: trimethylamine and dimethylamine mono-oxygenases, trimethylamine- $N$-oxide aldolase (demethylase), glutathione- and NAD-dependent formaldehyde dehydrogenase, dye-linked formaldehyde dehydrogenase, hydroxypyruvate reductase and $N$-methylglutamate dehydrogenase. Differential plots suggested that the rate of enzyme synthesis in the lag phase exceeded the rate of synthesis during exponential growth. The evidence suggests that the enzymes discussed are essential for growth on trimethylamine, while the NADPH-dependent $N$-methylalanine dehydrogenase is not involved.
\end{abstract}

\section{INTRODUCTION}

The catabolism of trimethylamine by methylotrophic bacteria involves a number of alternative pathways (Colby \& Zatman, 1973; Anthony, 1975). These differ in the following ways. Trimethylamine may be converted to dimethylamine via trimethylamine $N$-oxide (Boulton, Crabbe \& Large, 1974) or directly via a dehydrogenase-catalysed reaction (Colby \& Zatman, 1973, 1974). Dimethylamine may be converted to methylamine either via a monooxygenase (Eady, Jarman \& Large, I97I) or via a dehydrogenase (Meiberg \& Harder, 1976). Methylamine oxidation may proceed directly (Eady \& Large, I97I) or via $N$-methylglutamate (Hersh, Peterson \& Thompson, 1971; Bamforth \& Large, 1977) and/or $N$-methylalanine (Lin \& Wagner, 1975). In Pseudomonas aminovorans we have suggested (Jarman \& Large, 1972; Boulton et al., I974; Bamforth \& Large, 1977) that the pathway shown in Fig. I is operative. Parts of this pathway are based on work with other organisms.

We have previously shown (Boulton et al., 1974) that enzymes catalysing reactions I to 3 in Fig. I are induced before growth begins when succinate-grown $P$. aminovorans is transferred to trimethylamine growth medium. We present here an extension of this work in which we use differential plots (Monod, Pappenheimer \& Cohen-Bazire, 1952) to study the induction process, and demonstrate that growth on trimethylamine involves the prior synthesis of a number of other enzymes: $N$-methylglutamate dehydrogenase (reaction $6 \mathrm{~A}$ of Fig. I), NAD-dependent formaldehyde dehydrogenase (reaction 7) and hydroxypyruvate reductase (glycerate 2-dehydrogenase) (EC I.I.I.29 or I.I.I.8I). Hydroxypyruvate reductase is a key enzyme for carbon assimilation in methylotrophs which use the serine pathway (Quayle, I972; Large \& Carter, 1973). We also show that NADPH-dependent $N$-methylalanine dehydrogenase (reaction 5 in Fig. I) behaves in a way which indicates that it may not be required for growth on trimethylamine. 


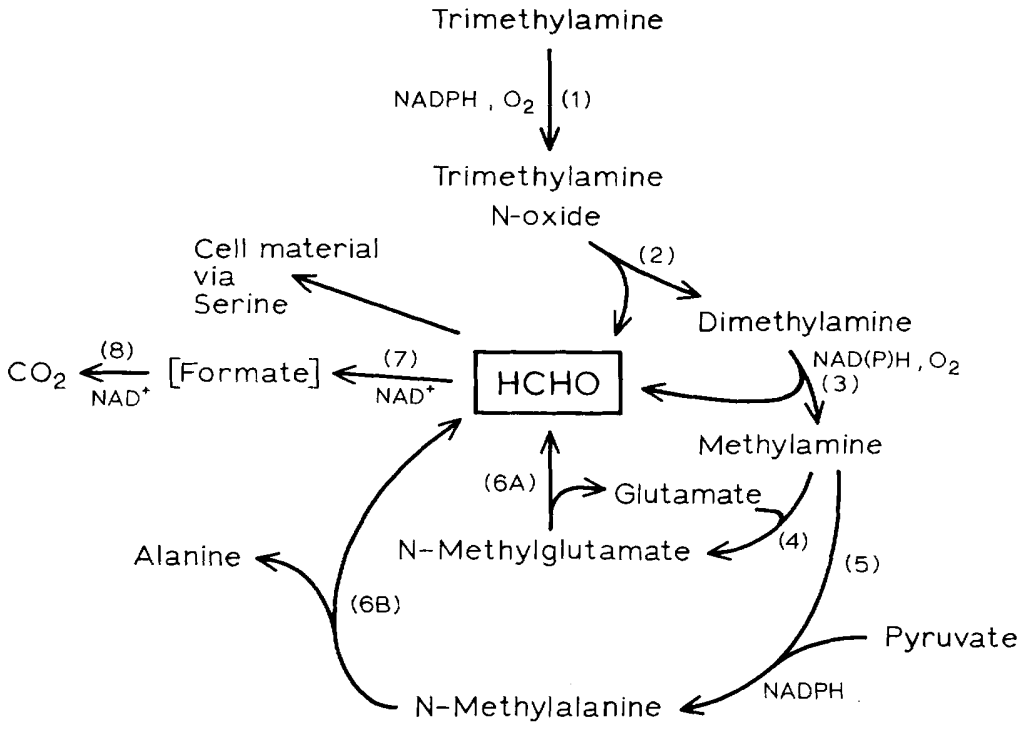

Fig. I. Reactions involved in the oxidation of trimethylamine in Pseudomonas aminovorans. Formaldehyde is the key intermediate between oxidation and assimilation. The enzymes are: (I), trimethylamine mono-oxygenase (similar to EC I. I4.13.8) (Boulton et al., 1974); (2), trimethylamine- $N$-oxide aldolase (demethylase), EC 4.I.2.- (Large, I97I); (3), dimethylamine monooxygenase, EC I . 14.99.- (Eady et al., I97I); (4), $N$-methylglutamate synthase, EC 2 . I I . 2 I (Pollock \& Hersh, I97I); (5), N-methylalanine dehydrogenase, EC I.5.1.-(Lin \& Wagner, 1975); (6A) and (6B), $N$-methylglutamate dehydrogenase, EC 1.5.99.5 (Hersh et al., I97I; Bamforth \& Large, I977); (7) formaldehyde dehydrogenase, EC I.2.I.I (Johnson \& Quayle, I964); (8) formate dehydrogenase, EC I.2.I.2 (Johnson \& Quayle, 1964).

\section{METHODS}

Growth and adaptation of bacteria. Bacteria were grown on salts medium B of Eady et al. (1971), with $19 \mathrm{~mm}$-sodium succinate as carbon source, in a 201 fermenter at $30^{\circ} \mathrm{C}$. The $\mathrm{pH}$ was maintained at 7.0 by periodic automatic addition of sterile alkali, and the culture was stirred vigorously and aerated at $51 \mathrm{~min}^{-1}$. Growth was followed turbidimetrically at $570 \mathrm{~nm}$. After $36 \mathrm{~h}\left(E_{570}=0.44\right)$, organisms were harvested aseptically by centrifuging ( $10000 \mathrm{~g}, 25^{\circ} \mathrm{C}$ ), resuspended $\left(160 \mu \mathrm{g}\right.$ dry wt organisms $\mathrm{ml}^{-1}, E_{570}=0.33$ ) in sterile medium containing $43 \mathrm{~mm}$-trimethylamine. $\mathrm{HCl}$ instead of succinate, and then returned to the fermenter and aerated as before. Samples (about $200 \mathrm{ml}$, or less, depending on the culture density) were removed hourly and $E_{570}$ was measured before centrifuging ( $12000 \mathrm{~g}, 5 \mathrm{~min}, 20^{\circ} \mathrm{C}$ ). The bacteria were then washed in $50 \mathrm{~mm}$-sodium-potassium phosphate buffer $\mathrm{pH} 7.0$, recentrifuged and finally resuspended in $7 \mathrm{ml}$ of the same buffer before storing in liquid nitrogen. The concentration of carbon source was measured in samples of the culture supernatant. The washed bacteria were later thawed, disrupted at $4{ }^{\circ} \mathrm{C}$ in a French pressure cell, centrifuged $\left(50000 \mathrm{~g}, 20 \mathrm{~min}, 4^{\circ} \mathrm{C}\right)$ and the supernatants were assayed to determine the specific activities of the enzymes shown in Fig. 2. The labile amine mono-oxygenases were assayed first. Much $N$-methylglutamate dehydrogenase $(60 \%)$ would have been sedimented and so not assayed: nocorrection was made for this. The protein content of exponential phase bacteria was $64 \%$ of the dry wt.

Enzyme assays. These were performed by published methods: trimethylamine mono-oxygenase, Boulton et al. (1974); dimethylamine mono-oxygenase, Eady et al. (1971); trimethylamine- $N$-oxide aldolase (demethylase), Large (197I); $N$-methylglutamate dehydrogenase, Bamforth \& Large (I977); $N$-methylalanine dehydrogenase, Lin \& Wagner (1975); hydroxypyruvate reductase, Large \& Carter (1973); glutathioneand NAD-dependent formaldehyde dehydrogenase, dye-linked formaldehyde dehydrogenase and formate dehydrogenase, Johnson \& Quayle (1964). All enzyme specific activities are expressed as munits (mg protein) ${ }^{-1}$ i.e. nmol product formed or substrate consumed $\min ^{-1}$ (mg protein $)^{-1}$.

Chemical estimations. Protein was measured by the method of Lowry et al. (195I). Succinate and trimethylamine in culture media were estimated enzymically by the methods of Rodgers (I96I) and Large \& McDougall (1975) respectively. 

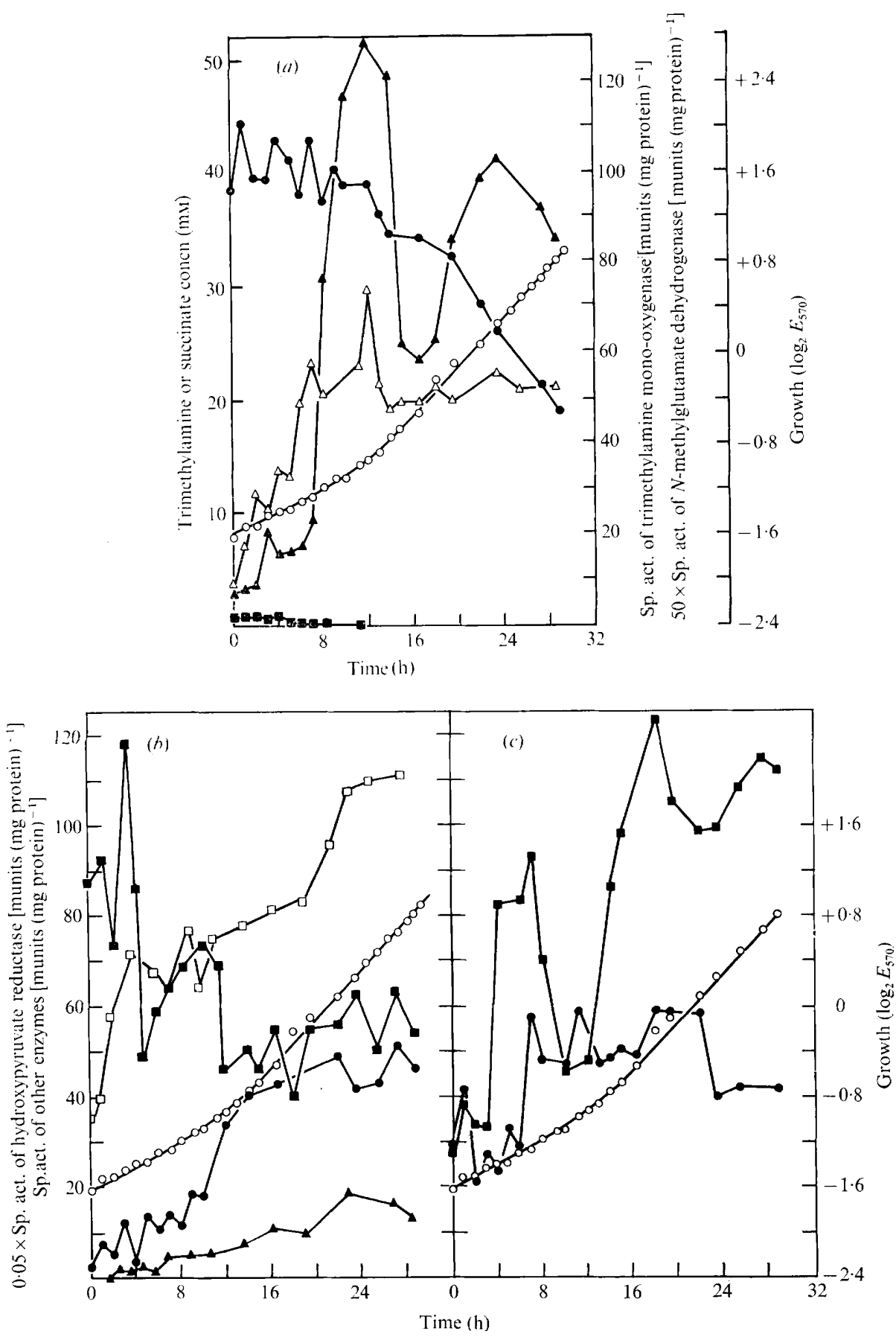

Fig. 2. Effect on enzyme levels of transfer from succinate to trimethylamine growth medium. Bacteria were grown on succinate, harvested aseptically without washing, and resuspended in trimethylamine growth medium as described in Methods. All data are from a single experiment.

(a) $\bigcirc$, Growth. Enzyme specific activities: $\triangle$, trimethylamine mono-oxygenase; $\Delta, N$-methylglutamate dehydrogenase. Concentration of carbon sources in the growth medium: $\mathbf{E}$, succinate; , trimethylamine.

(b) $\bigcirc$, Growth. Enzyme specific activities: $\bullet$, dimethylamine mono-oxygenase; $\mathbf{\square}, N$-methylalanine dehydrogenase; $\square$, NAD- and glutathione-dependent formaldehyde dehydrogenase; $\boldsymbol{\Delta}$, dyelinked formaldehyde dehydrogenase.

(c) $\bigcirc$, Growth. Enzyme specific activities: $\bullet$, trimethylamine- $N$-oxide aldolase (demethylase); $\mathbf{\square}$, hydroxypyruvate reductase. 


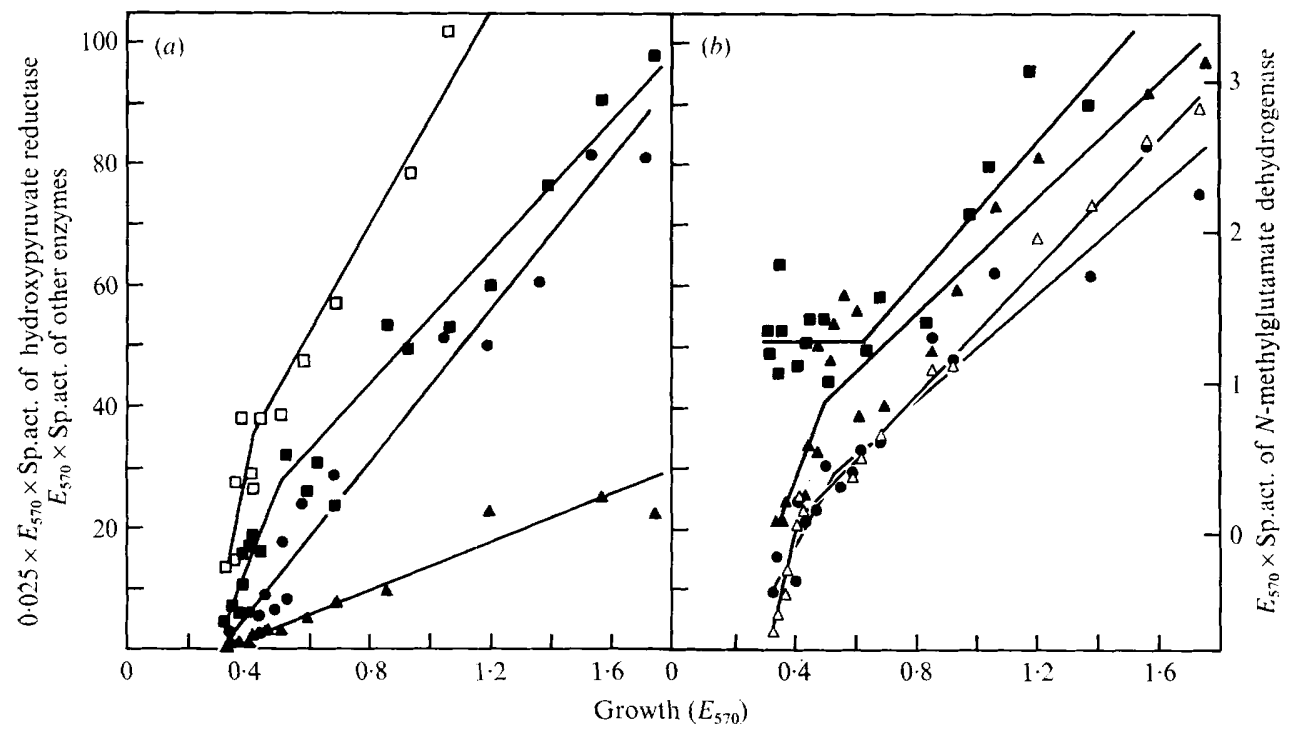

Fig. 3. Differential plots (Monod et al., 1952) of the data in Fig. 2.

(a) $\square$, NAD- and glutathione-dependent formaldehyde dehydrogenase; $\mathbf{m}$, hydroxypyruvate reductase; $\bullet$, dimethylamine mono-oxygenase; $\Delta$, dye-linked formaldehyde dehydrogenase.

(b) $\triangle$, Trimethylamine mono-oxygenase; $\bullet$, trimethylamine- $N$-oxide aldolase (demethylase); $\boldsymbol{\Lambda}, N$-methylglutamate dehydrogenase; $\boldsymbol{\square}, N$-methylalanine dehydrogenase (for clarity, the ordinate scale for this enzyme has been offset by 20 ordinate units).

\section{RESULTS}

The aim of the experiments was to obtain accurate estimates of the specific activities of most of the enzymes shown in Fig. I during the lag phase of adaptation of succinate-grown bacteria to growth on trimethylamine. Succinate-grown bacteria were harvested aseptically and transferred without washing to medium containing trimethylamine as carbon source. The small amount of sodium succinate left in the unwashed inoculum was not sufficient to repress the formation of the enzymes involved in trimethylamine metabolism and ensured that the lag in the adapting culture was short (Fig. 2). Without succinate the lag phase was very long and unpredictable.

Trimethylamine utilization could not be detected until the succinate was exhausted (Fig. $2 a$ ). Growth is expressed as $\log _{2} E_{570}$ which changes by one unit each generation (Monod, 1949). During the lag phase, which was a period of very slow growth rather than of no growth, a number of enzymes rapidly increased in specific activity: trimethylamine mono-oxygenase (Fig. 2a) and glutathione- and NAD-dependent formaldehyde dehydrogenase (Fig. 2b) appeared first, followed by hydroxypyruvate reductase (Fig. $2 c$ ), dimethylamine monooxygenase (Fig. $2 b$ ), dye-linked formaldehyde dehydrogenase (Fig. $2 b$ ), trimethylamine- $N$ oxide aldolase (demethylase) (Fig. $2 c$ ) and $N$-methylglutamate dehydrogenase (Fig. $2 a$ ) in approximately that order. The specific activity of $N$-methylalanine dehydrogenase (Fig. $2 b$ ) [which is involved in $N$-methylalanine formation in Pseudomonas Ms (Lin \& Wagner, 1975)] fell during the adaptation period and no NAD-dependent formate dehydrogenase activity (reaction 8 in Fig. I) was detected.

Differential plots of enzyme activity as a function of growth (Fig. 3) were biphasic for all the enzymes in Fig. 2 except dimethylamine mono-oxygenase and dye-linked formaldehyde dehydrogenase. In most cases the data showed correlation coefficients of 0.9 or higher when a linear-regression analysis program was applied to determine the best fit to straight lines of the data below $E_{570}=0.5$ and of the data above that value. The lines obtained by regression analysis are those drawn in Fig. 3. Most of the biphasic plots show an abrupt 
change in the differential rate of enzyme synthesis at an extinction of about 0.5 , which is approximately the time (about I I h in Fig. $2 a$ ) at which succinate in the medium is exhausted and exponential growth on trimethylamine begins. This can be equated with a period of rapid enzyme synthesis during the slow growth (or lag) period, followed by a slower rate representing the proportion of the enzyme in the bacterial cell during exponential growth on trimethylamine. The mean generation time during exponential growth under these conditions was approximately $9 \mathrm{~h}$. Some of the differential plots, e.g. those for $N$-methylglutamate dehydrogenase (Fig. $3 b$ ) and hydroxypyruvate reductase (Fig. $3 a$ ), are only arguably biphasic. In the case of $N$-methylglutamate dehydrogenase, this may be because the activities measured are very low and do not represent the total activity present in the cell, most of the activity being removed with the particulate fraction (see Methods). For $N$-methylalanine dehydrogenase (which, in contrast, is a soluble enzyme), the differential plot shows much scatter (Fig. $3 b$ ); even so, this enzyme behaves differently from the others in that there is no increase in activity during the lag phase.

\section{DISCUSSION}

Despite the inherent scatter in the data presented in Fig. 3, a biphasic pattern may be discerned in most of the differential plots. The only enzyme which does not consistently increase in specific activity during the adaptation period is $N$-methylalanine dehydrogenase. We interpret this as indicating that it probably does not play any role in growth on trimethylamine. In general, our evidence supports that part of the scheme in Fig. I leading up to and involving $N$-methylglutamate but not the part involving $N$-methylalanine. The low activity of $N$-methylglutamate dehydrogenase (even in membrane fractions, Bamforth \& Large, 1977) is not entirely consistent with our concept of its being a major enzyme on the pathway of amine oxidation as suggested in Fig. I, but this may be due to inherent difficulties in assaying this membrane-bound enzyme, as discussed elsewhere (Bamforth \& Large, 1977). The failure to detect NAD-linked formate dehydrogenase activity in these experiments is probably due to the non-inclusion of 2-mercaptoethanol in the buffers used to prepare the extract (Johnson \& Quayle, 1964), because whole bacteria readily oxidize formate and Eady (1970) found the enzyme in methylamine-grown P. aminovorans. Another possibility is that the enzyme may only show low activity with formate, since evidence has recently been presented that the true substrate of formate dehydrogenase in methylotrophic yeasts is $S$-formylglutathione, the product of the glutathione-dependent formaldehyde dehydrogenase (van Dijken et al., 1976).

\section{REFERENCES}

ANTHONY, C. (1975). The biochemistry of methylotrophic micro-organisms. Science Progress, $O x$ ford $62, \mathrm{I} 67-206$.

BAMForTH, C. W. \& LARGe, P. J. (1977). Solubilization, partial purification and properties of $N$ methylglutamate dehydrogenase from Pseudomonas aminovorans. Biochemical Journal 16r, 357370 .

Boulton, C. A., Crabbe, M. J. C. \& Large, P. J. (I974). Microbial oxidation of amines. Partial purification of a trimethylamine mono-oxygenase from Pseudomonas aminovorans and its role in growth on trimethylamine. Biochemical Journal 140, 253-263.

Colby, J. \& Zatman, L. J. (1973). Trimethylamine metabolism in obligate and facultative methylotrophs. Biochemical Journal r32, IOI-I I2.

Colby, J. \& Zatman, L. J. (1974). Purification and properties of trimethylamine dehydrogenase of bacterium 486. Biochemical Journal 143, 555-567. van Dijken, J. P., Oostra-Demkes, G. J., Otto, R. \& HARDER, W. (1976). S-Formylglutathione: the substrate for formate dehydrogenase in methanolutilizing yeasts. Archives of Microbiology III, 7783.

EADY, R. R. (1970). The bacterial oxidation of monoand dimethylamines. Ph.D. thesis, University of Hull.

EADY, R. R. \& LARge, P. J. (I97I). Microbial oxidation of amines. Spectral and kinetic properties of the primary amine dehydrogenase of Pseudomonas AMI. Biochemical Journal 123, 757$77 \mathrm{I}$.

EADY, R. R., JARMAN, T. R. \& LARGE, P. J. (I97I). Microbial oxidation of amines. Partial purification of a mixed function secondary-amine oxidase system from Pseudomonas aminovorans that contains an enzymically active cytochrome- $P$ 420-type haemoprotein. Biochemical Journal 125, 449-459. 
Hersh, L. B., Peterson, J. A. \& Thompson, A. A. (1971). An $N$-methylglutamate dehydrogenase from Pseudomonas MA. Archives of Biochemistry and Biophysics 145, I I5-I 20.

JARMAN, T. R. \& LARGE, P. J. (I972). Distribution of the enzymes oxidizing secondary and tertiary amines in Pseudomonas aminovorans grown on various substrates. Journal of General Microbiology 73, 205-208.

JoHNSON, P. A. \& QuAYle, J. R. (1964). Microbial growth on $\mathrm{C}_{1}$ compounds. 6 . Oxidation of methanol, formaldehyde and formate by methanol-grown Pseudomonas AMI. Biochemical Journal 93, 28I-290.

LARGE, P. J. (I97I). Non-oxidative demethylation of trimethylamine $N$-oxide by Pseudomonas aminovorans. FEBS Letters $\mathbf{1 8 , 2 9 7 - 3 0 0 .}$

LARGe, P. J. \& Carter, R. H. (I973). Specific activities of enzymes of the serine pathway of carbon assimilation in Pseudomonas aminovorans and Pseudomonas Ms grown on methylamine. Biochemical Society Transactions I, I29I-I 293.

LARGe, P. J. \& McDougall, H. (I975). An enzymic method for the microestimation of trimethylamine. Analytical Biochemistry 64, 304-310.

LIN, M. C.-M. \& WAgner, C. (1975). Purification and characterization of $N$-methylalanine dehydro- genase. Journal of Biological Chemistry 250, 3746-375I.

Lowry, O. H., Rosebrough, N. J., Farr, A. L. \& RANDALl, R. J. (I95I). Protein measurement with the Folin phenol reagent. Journal of Biological Chemistry I93, 265-275.

MeiberG, J. B. M. \& HARder, W. (I976). Aerobic and anaerobic degradation of trimethylamine and dimethylamine by Hyphomicrobium x. Proceedings of the Society for General Microbiology 4, 45.

MonOD, J. (1949). The growth of bacterial cultures. Annual Review of Microbiology 3, 371-394.

Monod, J., Pappenheimer, A. M., Jr, \& CohenBAzIRE, G. (I952). La cinétique de la biosynthèse de la $\beta$-galactosidase chez $E$. coli considérée comme fonction de la croissance. Biochimica et biophysica acta $9,648-660$.

Pollock, R. J. \& Hersh, L. B. (197I). N-Methylglutamate synthetase. Purification and properties of the enzyme. Journal of Biological Chemistry 246, 4737-4743.

QUAYLE, J. R. (1972). The metabolism of one-carbon compounds by micro-organisms. Advances in Microbial Physiology 7, 1 19-203.

RODGERS, K. (I96I). Estimation of succinic acid in biological materials. Biochemical Journal 8o, 240-245. 